\title{
The Use of Clusters to Build an ICT Industry
}

\author{
D.W. Maguire \\ Edith Cowan University, Perth, Western Australia
}

\author{
allmaguires@bigpond.com.au
}

\begin{abstract}
The potential in the Information and Computer Technology (ICT) sector to generate economic development and create pathways for a region into the Knowledge Economy (KE) has become widely accepted. Underpinning the theoretical understanding of what KE can offer has been the practical application of Porter's competitive theory relating to industry cluster development. The increasing role of clusters in $\mathrm{KE}$ and a greater focus on regional growth is seen in the development of a variety of dedicated technology zones aiming to emulate the success of Silicon Valley in the Unit ed States, the site of the original modern IT cluster.
\end{abstract}

\section{Introduction}

The first KE conference to be held in Australia attracted a range of interested parties that included the country's chief scientist, senior politicians, regional development practitioners, ICT industry leaders and entrepreneurs. The importance with which the event was regarded was as obvious as the depth of the participants' experience in information science. It signifies a turning point in Australia for KE and, as such, was "the big thing," an opportunity to learn what had been achieved in Australia and internationally, to hear what more was possible and to understand the imperative of progress. There was a session devoted to success stories about the role of clusters in the development of business and speakers referenced the theories of Michael Porter. The conference was held outside Sydney and sponsored by the regional development organization named the Office of Western Sydney (OWS). This region is home to 1500 IT firms and 220 biotech firms. OWS belongs to the government of New South Wales which hosts 75 of the top 100 Australian-based IT companies and employs 40 per cent of the total Australian ICT workforce.

The Australian conference is mentioned as an example of what has happened around the world in the past decade as countries adjust their thinking to the paradigms of the information age and what it means for their economies. They have witnessed a new economy spawned by the inventiveness of the scientists and free-thinkers of Silicon Valley and seen a need to be involved, whether it be manufacturing, designing or assembling products linked to the new technology. Hence, technology parks, enterprise centers, IT incubators, biotech hubs and the like have been built by governments that want to catch the wave through direct association.

Coinciding with the arrival of the information age in the mid-1990s was acceptance of Michael Porter's cluster approach to economic development espoused in The Competitive Advantage of Nations series

Material published as part of these proceedings, either on-line or in print, is copyrighted by Informing Science. Permission to make digital or paper copy of part or all of these works for personal or classroom use is granted without fee provided that the copies are not made or distributed for profit or commercial advantage AND that copies 1) bear this notice in full and 2) give the full citation on the first page. It is permissible to abstract these works so long as credit is given. To copy in all other cases or to republish or to post on a server or to redistribute to lists requires specific permission from the publisher at Publisher@InformingScience.org
(1985, 1990, 1998, 2000). His theory was applied to developing more integrated micro policies that enhance economic development and complement macro policies designed to achieve greater stability in the general economic environment. The cluster model can be applied to a multitude of industries however ICT has been a major driver of the world economy since the micro chip and per- 
Use of Clusters

sonal computer were developed and have changed the way we live. This paper looks at the clustering of the ICT industry around the world in the context of the Information/Knowledge Economy.

\section{Knowledge Economy, Clusters and Regional Development}

The OECD (1996) introduced the term "knowledge-based economy," defining it as an economy "directly based on the production, distribution and use of knowledge and information." The Asia-Pacific Economic Co-operation (APEC) economic committee defines a knowledge-based economy as one in which "the production, distribution and use of knowledge are the main drivers of growth, wealth creation and employment across all industries”. The United Kingdom's Competitiveness White Paper (Department of Trade and Industry, 1998) defines a knowledge-based economy as "...one in which the generation and exploitation of knowledge has come to play the predominant part in the creation of wealth".

Tapscott (2000) saw that no matter the name - human capital, intellectual capital, or knowledge capital the only assets that really count are intellectual assets, i.e. knowledge contained in the brains of knowledge workers and in networked digital documents and databases. His thesis was that the knowledge and creative genius of product strategists, developers and marketers was the key to the future. What counted was a company's ability to attract, retain and grow the capabilities of knowledge workers and to provide the environment for innovation and creativity. The Digital Age was not just an age of smart machines but of humans who, through networks, could combine their intelligence, knowledge and creativity for breakthroughs in the creation of wealth and social development.

The idea of industrial clusters forming the basis of regional economic growth has moved rapidly from academe to policy (Simmie \& Sennett, 1999). Two related lines of theoretical argument have been developed, mainly during the 1990s, which focus on conditions associated with endogenous regional economic growth. The first was inspired by the notion of flexible specialisation of Piore and Sabel (1984) and the re-invigoration of Marshall's (1919) concept of industrial districts by Becattini (1990). The second was Porter's (1990) work on the importance of industrial clusters for competitive advantage.

This paper relies on Porter's (1990, p. 149) definition: "a cluster consists of industries linked through vertical (buyer/supplier) or horizontal (common customers, technology, channels) relationships". Key features of clusters are internal networking, linkages and formal and informal interactions. A common strand in both the economic and sociological literature is the notion of local linkages forming a defining geographic basis of a cluster. These linkages tend more often to be based on commercial transactions in the economic analyses. The importance of non-traded linkages is more often stressed in economic sociology. In both cases by definition a cluster is said to exist by virtue of the existence of locally confined linkages.

Porter (2000) points to the paradox of economic geography during an era of global competition. It is recognised that changes in technology and competition have diminished many of the traditional roles of location. Yet, Porter finds, clusters, or geographic concentrations of inter-connected companies, are a striking feature of virtually every national, regional, state and even metropolitan economy.

The prevalence of clusters reveals important insights about the microeconomics of competition and the role of location in competitive advantage, he reports. Even as old reasons for clustering have diminished in importance with globalisation, new influences of clusters on competition have taken on growing importance in an increasingly complex, knowledge-based, and dynamic economy. Clusters represent a new way of thinking about national, state, and local economies, and they necessitate new roles for companies, government, and other institutions in enhancing competitiveness. 


\section{Silicon Valley the first IT cluster}

Silicon Valley is synonymous with the development of the ICT industry and is its original modern cluster grouping. Situated south of San Francisco, it has become the most intensely innovative enterprise zone in the world (Davidson, 2000).

The US Government (2000) recognized that over a period of 20 years it played a leading role in fostering the digital revolution that swept the globe: a revolution that led to productivity gains that helped create the longest economic expansion in U.S. history. The valley profited handsomely from the innovation of its residents and became one of the most prosperous communities in the country. It created more than 275,000 new jobs since 1992 and the median family income of its residents rose to \$US87,000 per year, the third highest in the country. The median price of a house in Silicon Valley rose to \$US410,000, more than twice that in the rest of the United States.

Silicon Valley started in 1938 (Of Mice and Men, 1997) when Stanford University electrical engineering professor Fred Terman convinced two of his students to start a company so they didn't need to go to the east coast for work. The students were Bill Hewlett and David Packard who set up a company making electronic measuring equipment in a garage behind the former's house. In the 1950s Hewlett-Packard, along with several other companies won over by Terman, moved into Stanford University's new industrial park. Hewlett-Packard's success attracted other firms.

Over the next two decades the number of young firms multiplied and attracted a network of specialist suppliers and service companies, including a new breed of venture capitalist. But progress was slow. A local technology journalist invented the name "Silicon Valley" - an allusion to its main industry, silicon chips - in 1971. Five years later Apple Computer was born in another garage. The personal-computer revolution was on its way.

Silicon Valley is a dynamic industrial cluster, which employs more than one million people, almost $40 \%$ of whom have at least a bachelor's degree, and more than a third are foreign-born. They are attracted by the good jobs and by the early access to frontier developments in the high-tech field. The Valley is loaded with startups and former startups such as Intel Inc. and Cisco Systems Inc. Venture capitalists invested more than \$6 billion in 1999 in new or young Valley companies, and 77 companies had initial public offerings, mainly related to the Net. Faculty and graduates of the strong science and engineering departments of two nearby universities, Stanford and the University of California at Berkeley, have been leaders in forming dynamic startups. While good universities may be necessary to develop these industrial clusters, they are not sufficient. Other regions with strong engineering schools, such as the University of Illinois at Urbana, do not have many high-tech companies. Whatever got Silicon Valley going, its advantages in attracting quality labor and venture capital multiplied as the region grew. A large pool of engineers, scientists, and software experts are available to both new and old companies. (Global Silicon Valleys? First kill all the Subsidies, 2000)

\section{IT Clusters in the Knowledge Economy}

Dozens of planned information technology communities, clusters or hi-tech parks are in some stage of government-sponsored development, as country's look to create the next Silicon Valley. So intense is the commitment towards the information/knowledge economy, that governments have become entrepreneurial in wooing the right sort of foreign direct investment, offering tax breaks, cheap labor, state-ofthe-art office space, high-speed Internet access, research labs, and cut-rate telecommunications. 
McGray (1999) notes the chief selling points of today's islands of IT expertise still revolve around proximity: proximity to a university, proximity to an influential market, proximity to competing and ancillary firms, proximity to new technologies and ideas. Although the rhetoric of information-age prophets suggests a trend toward decentralization, their industry - like entertainment, finance, or fashion - seems to maintain a particular affinity for clusters. Most countries will benefit from information technology in the long run, and a few will benefit tremendously, if they are patient. Despite widespread enthusiasm for a world without distance, some unlikely countries may build a booming high-tech sector by leveraging old-fashioned regional advantages and strong local loyalties. He notes the region surrounding Cambridge University boasts the densest concentration of high-tech expertise in Europe, with twelve hundred IT or IT-related firms employing thirty-eight thousand people.

In 1998, OECD member countries agreed on a definition of the ICT sector as a combination of manufacturing and services industries that capture, transmit and display data and information electronically (OECD, 2001). (See Figure 1, with numbers representing classes in the international standard classification of activities, ISIC Rev 3). The ICT sector makes a substantial contribution to economic activity in several OECD countries. In 1999, ICT value-added represented between 5\% and 14\% of total business sector value added. The importance of ICT supply has been growing. Rapid growth is apparent not only in countries like Hungary, the Czech Republic and Mexico, which are catching up in terms of infrastructure, but especially in northern European countries, such as Finland, Sweden, Norway, the Netherlands and the United Kingdom (Figure 2). In Finland, the ICT sector's share of value added increased by 4.7 percentage points over the $1995-99$ period and now represents over $13 \%$ of total business value added.

In most cases, services, such as telecommunication and computer services, constitute between $70 \%$ and $90 \%$ of total ICT sector value added. However, countries like Ireland, Finland, Korea, Japan and Mexico are specialised in the manufacture of ICT goods. In Finland, for example, the share of ICT in total manufacturing accounts for almost $20 \%$ of total manufacturing value added. Except for Ireland, where computing and office equipment account for almost $10 \%$ of manufacturing value added, the largest contribution to economic activity typically comes from the manufacture of telecommunication equipment.

Most OECD countries already have a well-developed telecommunication service sector that is reflected in the size of the ICT sector. At the same time, there is a noticeable increase in the contribution of computer and related services, mainly software services. The share of computer and related services in business services value added was highest in Sweden (5.8\% in 1999), Ireland (5.4\% in 1998), and the United Kingdom (4.1\% in 1999). 


\section{Singapore It Cluster}

Singapore recognized the benefits of the Knowledge Economy as it emerged in the late 1990s, and in early 2000 the government decided to switch from its highly successful but IT-superseded economic model. It launched the Industry 21 project to develop knowledge-based industries for the next 10 years, diversifying among and within key industry clusters to achieve sustainable growth and minimize vulnerability to fluctuation in specific sectors. Tan (2000) quoted Senior Minister Lee Kuan Yew who spoke of the need for "creative destruction" to take place to chart new paths if governments and their people were going to be bold enough to stop clinging on to past successes:

That which did us good in the phase that was, will not do us good in the next 20, 30 years. We start changing our mindsets now.

Tan recognized the new economy as a radically new way of thinking and doing and saw speed, flexibility and nimbleness in seizing market opportunities combined with the presence of entrepreneurial talents and technological expertise as critical. There was a need for incumbent businesses from the old economy to make wrenching changes to embrace the new and recognized the need for young, insurgent start-ups to catch the next wave of technological change.

The country went through major paradigm shifts to get to the new Knowledge Economy approach and to focus on growth clusters, Hwa (2002), managing director of the Singapore Economic Development Board, told the Australian KE conference. Now, red tape has been replaced by red carpet to welcome businesses to an enterprise eco-system where they are invited to "plug and play". Singapore aims to focus on sectors and encourage overseas enterprises, effectively spotting companies in other countries and hunting them down. It intends to transform the country into a high-tech magnet.

Singapore's main industry clusters are nearly all linked to the Knowledge Economy. Its electronics/precision engineering cluster produces a third of the world's hard-disc drive output, its chemical cluster oversees the highest concentration of chemicals activities after Rotterdam and the US Gulf Coast, its Infocomms \& Media cluster hosts 70 of the world's top 100 IT companies and Singapore is home to 15 regional satellite broadcasters and its logistics and transport cluster is a world leader in jack-up oil rig manufacturing as well as running one of the world's busiest ports.

It continues to reinvent itself as an economy through new growth clusters - including nanotechnology and phototonics as well as biomedical sciences and education services - and a web of international free trade agreements.

\section{Scotland IT Cluster}

Most of the world players are present in Scotland's electronics industry and almost half of the PCs sold in Europe are assembled there. A semi-conductor industry cluster was set up by Scottish Enterprise in the late 1990s under its charter to manage the country's economic development and it has sales of around $\$ 3$ billion, representing about 2 per cent of the world market (Carrie, 1999). Scottish Enterprise 
was cognizant of its cluster heritage, forged a century ago by one of the strongest clusters in the world in the ship-building industry and the phrase "Clyde-built" became a by-word of dependability.

Peters and Hood (2000) studied the success of the cluster approach to the semi-conductor industry, starting from 1998 when as a result of direct investment from the United States and Japan, around 7000 people were employed in the field. The five main facilities included NEC and Motorola, the world's second and third largest fabricators, after Intel. They found that:

- in spite of being located within

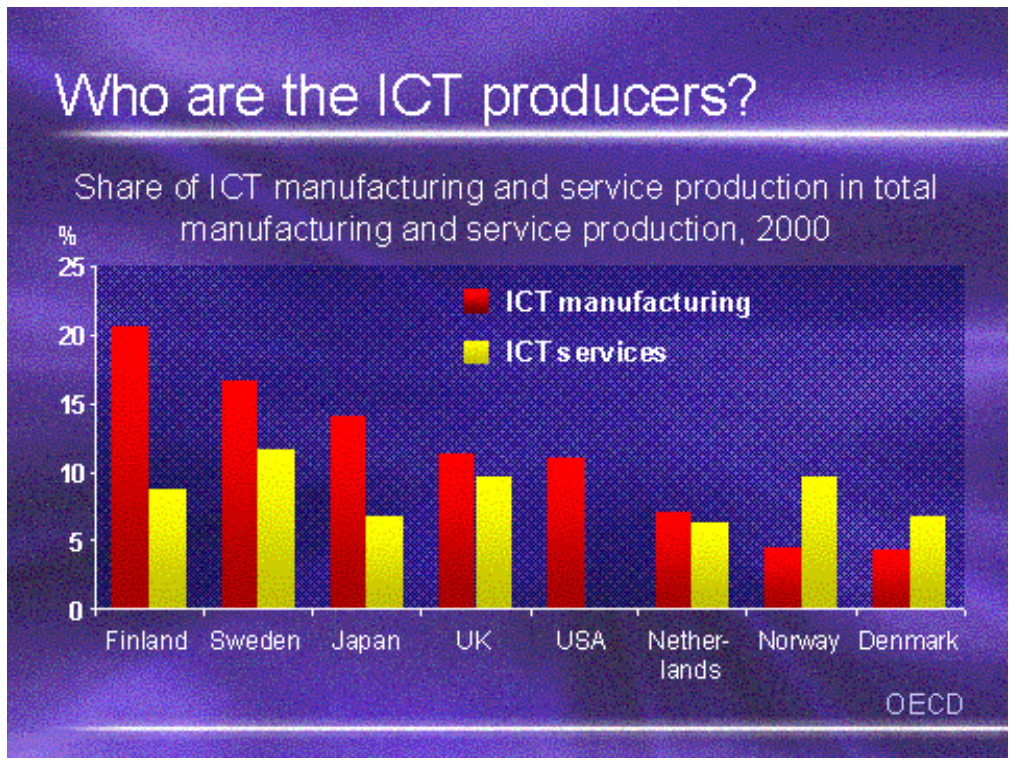

Figure 3: Stand-out ICT producers (Colecchia, 2001) an information-industries cluster, almost all of the \$2-3 billion semi-conductor output was exported; conversely most of the \$56 billion value of semi-conductors built into electronics goods produced in Scotland is imported from outside the country.

- Linkages to a well-developed local knowledge base were recognized as the strategic imperative and needed to be further strengthened in leading-edge technologies generated from local universities

The semi- conductor cluster was assessed as an important vehicle for rapidly moving Scotland's information industries from their increasingly vulnerable position as a low cost manufacturing and logistics hub to a more defensible mid-term position as a value-added leader in core competencies.

\section{Finland It Cluster}

Finland (Figure 3) offers one of the world's most sophisticated ICT infrastructure and application environments and provides cutting-edge, high efficiency settings for all kinds of business. Nokia, Finland's largest company, is the world's leading mobile phone supplier and a leading supplier of mobile, fixed and IP networks, as well as multimedia terminals. Finland is also home to many niche leaders in related fields such as mobile commerce, wireless equipment and data security. Approximately two-thirds of Finnish software companies develop and produce ICT software.

But it wasn't always so. Finland was highly agricultural and one of the poorest countries in Europe through the 1800s and early 1900s, known mainly for its forestry output until World War II when it developed a machine industry. During its period as a Russian Grand Duchy up to the early 1900s, it was home to hundreds of independent telephone companies so had a heritage of building telecommunications infrastructure to service its geographically dispersed population.

The competitive knowledge in networking and being early adopters of new technology to beat a rival company has helped in the transition since the end of the war to the Information Age, so much so that Finland's economic strength now comes from developing high-technology exports(Figure 4) at a rate which make it a world leader in the ICT industry. The industry is so large and globally influential that Finland's high-technology exports exceed its imports, a factor which is unique among OECD countries. It is among the world's wealthiest countries as a result of the transformation from a commodity-based economy to a leading-edge manufacturer of new communications technologies. 
Critical to getting to the current level was the Finnish ICT equipment industry cluster that centres on telecommunications equipment manufacturing and service provision. With 75,000 employees in 1998, the cluster accounted for 3 per cent of the total national employment, with Nokia alone employing 21,000 persons in Finland and dominating the cluster both by size and effect. Paija (2000) builds a thesis that the Finnish ICT cluster has been evolving for 100 years on the basis of nonregulation and full competition and the subsequent growth of its member companies through successes - like manufacturing the world's first mobile phone - have reduced the country's dependence on fluctuating raw material based-industries, such as forestry and paper.

Thus, the cluster creates an environment critical to the health of the economy and causes government to become closer and more active with the public sector than in other countries.

\section{Irish IT Cluster}

Ireland has one of the highest concentrations of ICT activity and employment in the OECD, principally in electronics hardware manufacture, such as PCs, PC components and office machinery, software products and services and call centers. It is the fifth largest exporter of computers in the world, they account for more than a third of all Irish exports and a third of PCs sold in Europe are made in Ireland.

This has not been achieved overnight or by accident and goes back to 1960 when the economy was restructured as a precursor to gaining entry to the European Union (EU) in 1973. The restructure involved opening the economy to external trade and lowering tariff barriers as well as dedicated investment in education and infrastructure.

Once EU entry was gained Ireland promoted itself as the gateway to Europe and the Irish Trade Board promoted Irish exports. Foreign direct investment was sought in three stages, first for start- up electronics, pharmaceuticals, engineering and later software industries, secondly for R\&D and head office setups in companies and R\&D in universities and, thirdly, indigenous managers spinning off new start-ups and university incubators spinning out new companies.

Ireland has been termed the "Celtic Tiger" because of its similarity to East Asian economic successes in the late 1990s. Its success (Garvey, 2002) is strongly linked to R\&D in the universities and that it was focused on new industries.

ICT clusters drive the industry in Ireland and are located in Dublin, the largest, with smaller regional clusters in Cork, Limerick/Shannon and Galway, the latter including Nortel and over 50 small and medium-sized companies.

New key opportunity sectors being targeted by Ireland are infomatics, digital media, Ebusiness and Health Sciences and to facilitate them a digital cluster has been set up to create a center of excellence for innovation, creativity, research and learning focused on developing new and existing media enterprises. 
Use of Clusters

This has lead to the creation of a new marketplace in the oldest market areas of Dublin, with state of the art infrastructure installed in a culturally important building with links to the Guinness dynasty. This center will be a hub for leading-edge creative enterprises developing:

- games, animation, e-learning niches

- distribution models

- information technology enablers

- $\quad$ linked to R\&D through Media Lab Europe

Called MediaLab Europe, it is an alliance between the Irish Government and MIT's Media Laboratory in the United States that has been established to drive technology research and link it to enterprise outcomes.

\section{Israel IT Cluster}

The Economist (Silicon Envy, 1999) labeled Israel as California's most likely rival, citing a "close knit society that networks ceaselessly, deals daily with risk, reveres learning, and is blessed with a torrent of well-educated immigrants from the former Soviet Union."

Israel's hi-tech industry has been driving the country's economy since the early 1990s (Feldman \& Abuganim, 2002) in its quest to evolve its Silicon Wadi as the next Silicon Valley. This is hardly surprising given Israel was estimated in 1998 to have the world's largest scientist population, with 135 engineers per 10,000. In recent years, mirroring the situation throughout the developed world, the focus of the industry has increasingly centred on the Internet, and latterly wireless technology.

Berry (2002) noted that Israel's success generators included striving for excellence in a few fields of study and research, including developing hardware and software for the ICT industry. There has been an emphasis on higher education with a continual focus on technology and science and broad information and educational exchange links developed with the United States in academia and software development. Israel's thriving young high-tech sector is anchored by one of the finest university systems in the world.

By the end of the 1990s, Israel had formed one of the world's most successful high- technology clusters (de Fontenay \& Carmel, 2001). It consists of software, data communications, electro-optics, hardware design, and Internet technologies, which together generated $\$ 15$ billion in export revenues in 2000. One important key to its success has been long-term advantages that Israel possesses in ICT, enhanced by short-run exogenous factors that hastened the formation of the cluster during the 1990s, and produced strong cluster effects. Israel's long-term comparative advantage is based on its endowments of production factors for labor-based high technology (Figure 5): A stock of high-skilled labor, research knowledge in some specific areas
Percent of employed persons in High-Tech Activities from total employed persons by

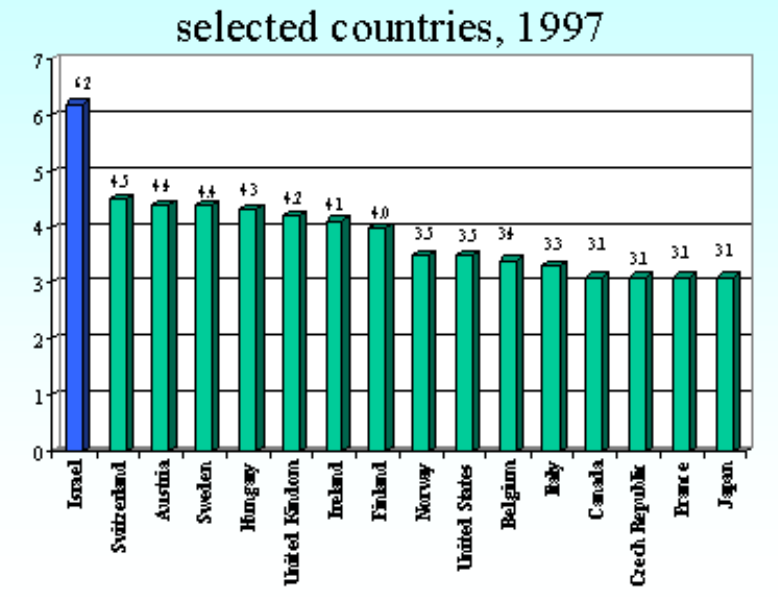

Figure 5: Israel has a clear lead in ICT employment (Source: Central Bureau of Statistics, State of Israel, 2002) 
within IC T such as data security, and an abundance of relevant entreprene urial and organizational skills.

McGray (1999) notes that Israel, in the waning years of Soviet communism, was suddenly faced with a massive influx of highly skilled Russian immigrants. In order to capitalize on this unexpected new resource - one million Russians in 10 years who were disproportionately trained and highly educated - the government launched a network of 27 incubators, high-tech complexes designed to help both immigrants and native Israelis collaborate and commercialize innovations with federal venture capital.

The Israeli Government, which plays an important role in fostering the country's venture capital bus iness, also helped set the stage for the development of the country's thriving communications industry. In 1984 it converted the telephony and telecommunications services from a government service to a go vernment-operated company, the Israeli PTT. This infrastructure now provides a full digital service throughout the country, with ISDN, ATM, fibre-optic and satellite services.

A range of advantages, such as government tax incentives and skilled labour, mean Israel has long been popular with US and European technology companies. The arrival of these multinationals, most notably Motorola and Intel in the 1970s, also helped spark off the technology industry, as they brought experience and working practices lacking in Israel at the time. The country's expertise in raising venture capita for the ICT industry has lead in recent years to the formation of a cluster for the VC industry.

\section{Conclusion}

This paper has highlighted where individual national ICT industries have benefited from the formation of regional cluster groups. The examples chosen have been some of the most successful in the new Knowledge Economy and have set the standard for others to follow. As regions become aware through learning what other economies have achieved they recognize the potential to become involved with the result that the global ICT industry will spread further around the world. One element critical to the success of ICT clusters has been the high educational standard of the labour force available to the industry and the importance of collaboration with right-thinking tertiary institutions. It is a paradox that the modern world's first ICT cluster in Silicon Valley, USA, grew without government support while those that are being created to emulate it are being engineered to success by government.

\section{References}

APEC Economic Committee. (2000). Towards Knowledge-based Economies in APEC.

Becattini, G. (1990). The Marshallian industrial district as a socio-economic notion. in Pyke, E, Becattini, G \& Sengenberger, W (eds), Industrial Districts and Inter-firm Co-operation in Italy, Geneva, International Institute for Labour Statistics, pp. 37-51.

Berry, O. (2002). Israel - Industrial science and technology policy. Proceedings of the Moving Towards the Knowledge Economy Conference - Shaping Australia's Future, Office of Western Sydney, NSW, Australia.

Carrie, A. (1999). Integrated clusters - the future basis of competition. International Journal of Agile Management Systems, Bradford, UK, Vol 1, Issue 1, pp. 45-50.

Colecchia, A (2001) The New Economy and the Role Played by the ICT Producing Sectors: Recent Trends and Comp arisons Across OECD Countries, Proceedings of the Official Statistics and the New Economy IAOS Conference, London

Davidson, A. (2000). Into the valley, Management Today, November, Haymarket Publishing Ltd, p. 72.

De Fontenay, C. \& Carmel, E. (2001). Israel's silicon wadi: The forces behind cluster formation. SIEPR Policy Paper No 0040, Stanford University.

Department of Trade and Industry. (1998). Building the Knowledge-Driven Economy, United Kingdom Government, Whitehall, London.

Feldman, M. \& Abuganim, M. (2002). Development of Israel high-tech sector 1995-1999: Labour force and wages. Proceedings of the Official Statistics and the New Economy Conference, London. 
Use of Clusters

Garvey, M. (2002). Towards a knowledge economy. Proceedings of the Moving Towards the Knowledge Economy Conference - Shaping Australia's Future, Office of Western Sydney, NSW, Australia.

Global Silicon Valleys? First kill all the Subsidies. (2000). Business Week, March 27, The McGraw-Hill Companies, Inc, p. 26.

Hwa, K.K. (2002). Singapore's economic development thrusts. Proceedings of the Moving Towards the Knowledge Economy Conference - Shaping Australia's Future, Office of Western Sydney, NSW, Australia.

Marshall, A. (1919). Principles of Economics, Industry and Trade, Macmillan, London.

McGray, D. (1999). The Silicon archipelago - The next generation: Work in progress (planned information technology communities similar to Silicon Valley), Daedalus, Spring, Vol 128, Issue 2, p. 147.

OECD. (1996). The Knowledge-Based Economy. OECD Paris.

OECD. (2001). Science, Technology and Industry Scoreboard, 2001, Towards a Knowledge Based Economy; B.7.1. Size and Growth of the ICT Sector. http://www1.oecd.org/publications/e-book/92-2001-04-1-2987/B.7.1.htm

Of Mice and Men. (1997, 29 March). The Economist US Edition.

Paija, L. (2000). ICT cluster - The engine of knowledge-driven growth in Finland. Discussion Papers. The Research Institute of the Finnish Economy, No 733. Helsinki, Finland.

Peters, E. \& Hood, N. (2000). Implementing the cluster approach. International Studies of Management \& Organisation. Summer 2000, Vol 30, Issue 2, p. 68.

Piore, J.M. \& Sabel, C.F. (1984). The Second Industrial Divide: Possibilities for Prosperity, Basic Books, New York.

Porter, M.E. (1985). Competitive Advantage. Free Press, New York.

Porter, M.E. (1990). The Competitive Advantage of Nations. Free Press, New York.

Porter, M.E. (1998a). The Competitive Advantage of Nations (New Introduction). Macmillan Business, London.

Porter, M.E. (1998b). Clusters and the new economics of competition. Harvard Business Review, Vol 76, No 6, pp77-90.

Porter, M.E. (2000). Location, competition, and economic development: Local clusters in a global economy. Economic Development Quarterly, Sage Publications, Thousand Oaks.

Silicon Envy. (1999, 20 February). The Economist US Edition.

Simmie, J. \& Sennett, J. (1999). Innovative clusters: Global or local linkages? National Institute Economic Review. London.

Tan, T. (2000). Singapore: Forging into the new economy. Zdnetasia. www.zdnetasia.com

Tapscott, D. (2000). Minds Over Matter. Business 2.0. www.business2.com/content/magazine/indepth

US Government. (2000). White House fact sheet on digital divide and East Palo Alto, California. COMTEX News Network, Inc., Washington, DC.

\section{Biography}

D.W. Maguire is a Doctor of Business Administration (Information Systems) candidate at Edith Cowan University in Perth, Western Australia. A Master of Business Administration and Master of International Tourism Management, he is a former journalist, editor and newspaper manager. His research interests cover a range of topics including information management, the knowledge economy and the application of clusters in building regional economies. 